\title{
Cyril Connolly, November 1974
}

New York Review of Books (24 June 1976)

This hews you to your statue :

Flakes away the flesh

Back to bone intellect :

Lays bare the brow, pure semi-circle,

Star-striking dome -

Sidera sublime vertice -

Proves finally the head was Roman.

This seals your eyelids : sharpens

The nose, so sensual once,

To a pure triangle; this drills

Into the base, the nostrils.

Hid in the creviced mouth

Only the palate still

Savours the must of dying.

She who leans over

Your shoulder, from which the sheet

Stretches in outline to the feet,

Tugs it to make you

Recognize me : 'Don't! I pray, don't!

Don't let him see me seeing

His onyx eyeballs shout at me from marble!' 